MONIKA CHMIELEWSKA-DZIKIEWICZ ${ }^{1}$

\title{
Asesor sądowy w polskim porządku prawnym a realizacja konstytucyjnej zasady niezawisłości sędziów i niezależności sądów. Wybrane zagadnienia ${ }^{2}$
}

\section{Streszczenie}

$\mathrm{W}$ artykule przedstawiono status asesora sądowego $\mathrm{w}$ sądownictwie powszechnym na mocy obowiązujących przepisów prawnych. Na potrzeby opracowania wybrane zostały najważniejsze uprawnienia asesora w odniesieniu do zasady niezawisłości sędziowskiej i niezależności sądów. Przybliżone zostały także najważniejsze etapy kształtowania się instytucji asesora sądowego od 1928 roku.

Słowa kluczowe: asesor sądowy, zasada niezawisłości sędziowskiej, sędzia

1 Monika Chmielewska-Dzikiewicz - uczestnik prawniczego seminarium doktoranckiego w Akademii Leona Koźmińskiego w Warszawie, aplikant adwokacki w Izbie Adwokackiej w Warszawie; e-mail: chmielewska.dzikiewicz@gmail.com.

2 Stan prawny na 31 grudnia $2018 \mathrm{r}$. 


\title{
Assessor of the polish court and the implementation of the constitutional rules for the reliability of judges and the independence of the courts. Selected issues
}

\begin{abstract}
The article presents the status of an assessor in the court of law in accordance with applicable legal provisions. For the needs of the study, the most important competences of the assessor were chosen in relation to the principle of judicial independence and independence of the courts. Additionally, the most important stages of shaping the institution of the assessor from 1928 were also approximated.
\end{abstract}

Keywords: court assessor, assessor, principle of judge independence, judge 
I nstytucja asesora sądowego co do zasady ma na celu zweryfikowanie w praktyce umiejętności orzeczniczych, wiedzy oraz cech osobowościowych przyszłego sędziego. Jest ona od dawna znana w polskim sądownictwie. Została wprowadzona do polskiego porządku prawnego w 1928 r. ${ }^{3}$ i funkcjonowała przez dziesięciolecia, chociaż status asesora i zakres jego kompetencji zmieniały się na przestrzeni lat. Po wielu zawirowaniach prawnych oraz wyrokach Trybunału Konstytucyjnego ${ }^{4}$ i Europejskiego Trybunału Praw Człowieka ${ }^{5}$ (do których powrócę w dalszej części tekstu) instytucja ta cały czas ewoluuje. W niniejszym artykule przeanalizuję obowiązujące regulacje prawne pod kątem pytania, czy instytucja asesora sądowego spełnia konstytucyjne gwarancje niezawisłości sędziowskiej i niezależności sądów. Ponadto przedstawię opinie środowisk prawniczych wskazujące na ewentualne problematyczne kwestie, które w praktyce mogą budzić wątpliwości prawne.

Na początek warto jednak przypomnieć najważniejsze etapy kształtowania się instytucji asesora sądowego w Polsce, co da nam szerszą perspektywę w kontekście obecnych licznych zmian legislacyjnych. Odnosząc się do historii, należy zacząć od wspomnianego już roku 1928, w którym zapoczątkowano funkcjonowanie asesorów sądowych na mocy rozporządzenia Prezydenta RP regulującego ustrój sądów powszechnych. Zgodnie z ówcześnie obowiązującymi przepisami asesor mógł pełnić czynności sędziowskie (tzw. wotum) powierzane przez prezesów sądów. W czasie ich sprawowania asesorzy mieli zagwarantowaną nieusuwalność, ale nie przysługiwało im prawo do wydawania wyroków. Co ciekawe, niezmiennie od 1928 r., pomimo licznych nowelizacji, utrzymywano uprawnienie Ministra Sprawiedliwości do mianowania asesorów sądowych. W Polskiej Rzeczypospolitej Ludowej asesorom sądowym przyznano prawo wydawania orzeczeń, a odbycie asesury stało się warunkiem koniecznym przed powołaniem na urząd sędziego. Minister Sprawiedliwości otrzymał uprawnienie powierzania asesorom prawa pełnienia obowiązków sędziego, a ustawa gwarantowała im niezawisłość w zakresie

3 Zob. Rozporządzenie Prezydenta Rzeczypospolitej z dnia 6 lutego 1928 r. Prawo o ustroju sądów powszechnych (Dz.U. z 1928 r., nr 12, poz. 93).

$4 \quad$ Zob. Wyrok Trybunału Konstytucyjnego z dnia 24 października 2017 r., SK 7/06.

5 Zob. Wyrok Europejskiego Trybunału Praw Człowieka z dnia 30 listopada 2010 r., skarga nr 23614/08, Urban vs Polska; Zob. Wyrok Europejskiego Trybunału Praw Człowieka z dnia 14 czerwca 2011 r., skarga nr 36921/07, Garlicki vs. Polska. 
orzekania ${ }^{6}$. W latach 50. XX w. można było zauważyć zbliżenie się w swoim kształcie instytucji asesora sądowego do urzędu sędziego i rozszerzenie uprawnień Ministra Sprawiedliwości ${ }^{7}$. W ciągu następnych lat ta tendencja utrzymywała się bez większych zmian, a w 2001 r. ustawą Prawo o sądach powszechnych ${ }^{8}$ potwierdzono ich dotychczasowy status. Minister Sprawiedliwości mianował asesorów na czas określony w sądzie rejonowym. Należało do niego również powierzenie im obowiązków sędziego, chociaż dodatkowo zależało ono od zgody kolegium sądu okręgowego. Krajowa Rada Sądownictwa nie uczestniczyła w tej procedurze. Asesorzy sądowi mieli przyznane prawo wydawania orzeczeń. Podczas pełnienia funkcji przydzielano im sędziego konsultanta, który służył wsparciem merytorycznym ${ }^{9}$. Rola sędziego konsultanta budziła wiele kontrowersji, ponieważ z jednej strony zastanawiano się, czy nie ma on wpływu na merytoryczne rozstrzygnięcie orzeczenia, z drugiej zaś rzeczywiście stanowił on niezbędne wsparcie z zakresu metodologii pracy sędziego dla jeszcze niedoświadczonych asesorów ${ }^{10}$. W opinii T. Zembrzuskiego odnośnie do ówczesnego stanu prawnego na mocy obowiązujących przepisów prawnych „ustawodawca zrównał status sędziego i asesora w zakresie władzy orzeczniczej, lecz podmiot ten nie spełniał jednak niezbędnych gwarancji niezawisłości właściwych sędziom"11. Przypuszczenia te okazały się uzasadnione.

Momentem przełomowym w historii instytucji asesora sądowego był wyrok Trybunału Konstytucyjnego z dnia 24 października 2007 r. ${ }^{12}$, w którym za niezgodny z Konstytucją uznano przepis dotyczący powierzania asesorom obowiązków sędziego przez Ministra Sprawiedliwości ${ }^{13}$. Chodziło przede wszystkim o równoczesną możliwość odwołania asesora pełniącego wotum, co stanowiło naruszenie

6 D. Malec, Czy asesor byt sędzią? Instytucja asesora sądowego w prawie o ustroju sadów powszechnych $w$ Polsce od okresu dwudziestolecia międzywojennego. Wybrane zagadnienia, "Gdańskie Studia Prawnicze” 2012, t. XXVII, s. 245-253.

7 J. Bodio, Instytucja asesora sadowego, „Studia Iuridica Lublinensia” 2010, nr 13, s. 75.

8 Ustawa Prawo o sądach powszechnych z dnia 27 lipca 2001 r. (Dz.U. nr 98, poz. 1070).

9 D. Malec Asesor sądowy - udana reaktywacja historycznej instytucji czy nietrafna nowelizacja Prawa o ustroju sądów powszechnych?, w: Nil nisi veritas. Księga dedykowana Profesorowi Jackowi Matuszewskiemu, red. M. Głuszak, D. Wiśniewska-Jóźwiak, Łódź 2016, s. 529-537.

10 J. Bodio, op. cit., s. 79-80.

11 Cyt. za: T. Zembrzuski, Status ustrojowy asesora sądowego przed powierzeniem mu czynności sędziego, „Monitor Prawniczy" 2018, nr 19, pkt I, https://sip.legalis.pl/document-full.seam?documentId= mjxw62zogi3damrqheytony\#tabs-metrical-info (dostęp: 22.12.2018).

12 Wyrok Trybunału Konstytucyjnego z dnia 24 października 2017 r., SK 7/06.

13 Uzasadnienie wyroku Trybunału Konstytucyjnego z dnia 24 października 2017 r., SK 7/06, pkt 5.1, 6.1, https://sip.legalis.pl/document-full.seam?documentId=mrswglrwguytamzxga3a (dostęp: 10.05.2018). 
zasady niezawisłości sędziowskiej i niezależności sądów. Trybunał podzielił wątpliwości co do mnogości uprawnień Ministra Sprawiedliwości - przedstawiciela władzy wykonawczej - względem asesora i zalecił, aby przyszłe uregulowania prawne gwarantowały „rzeczywiste oddzielenie trzeciej władzy od innych władz, rozluźniły więź między asesorami i ministrem sprawiedliwości"14. Co ważne, Trybunał Konstytucyjny nie zanegował możliwości istnienia instytucji asesora sądowego po odpowiednich zmianach w prawie, gdyż, jak stwierdził w uzasadnieniu, „Konstytucja z założenia nie reguluje całościowo problematyki funkcjonowania władzy sądowniczej. (...) Powierzenie wykonywania władzy sądowej osobom o statusie zbliżonym do sędziów, z zapewnieniem im formalnie cechy niezawisłości w orzekaniu, nie stanowi wprost naruszenia konstytucyjnego statusu sędziego ani zasady niezawisłości w jej materialnym rozumieniu"15.

Europejski Trybunał Praw Człowieka (dalej: ETPCz) także zajmował się zagadnieniem niezawisłości asesorów sądowych pełniących obowiązki sędziego. W spra-

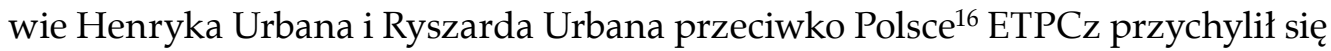
do ustaleń poczynionych w wyżej wspomnianym rozstrzygnięciu Trybunału Konstytucyjnego i uznał możliwość odwołania asesora w trakcie pełnienia wotum przez Ministra Sprawiedliwości za niedopuszczalną. Skrytykowano brak przyznania asesorom odpowiednich gwarancji niezawisłości mających na celu ich ochronę przed ingerencją ze strony innych władz. Strona polska próbowała bronić regulacji prawnych, tłumacząc, że asesorzy orzekają w sądach rejonowych jako sądach pierwszej instancji, a każdy uprawniony ma prawo odwołania się do sądu drugiej instancji, który przecież składa się już tylko z sędziów zawodowych, co stanowi stosowne zabezpieczenie i gwarancję, że wyrok zostanie wydany przez niezależny i niezawisły sąd. ETPCz, odnosząc się do tego zagadnienia, uznał, że postępowanie toczące się przed drugą instancją nie zniweluje naruszeń powstałych w pierwszej instancji przeprowadzonej przez asesora, który nie jest niezawisły ${ }^{17}$. Na podobnych zarzutach opierało się rozstrzygnięcie w sprawie Garlicki przeciwko Polsce ${ }^{18}$, kiedy to asesor wydał decyzję dotyczącą tymczasowego aresztowania. Również w tym przypadku ETPCz stwierdził, że urzędnik uprawniony przez ustawę do orzekania

14 Cyt. za: Uzasadnienie wyroku Trybunału Konstytucyjnego, op. cit., pkt 6.1.

15 Cyt. za: Uzasadnienie wyroku Trybunału Konstytucyjnego, op. cit., pkt 3.4.

16 Wyrok Europejskiego Trybunału Praw Człowieka z dnia 30 listopada 2010 r., skarga nr 23614/08, Urban vs. Polska.

17 Przeglad orzecznictwa europejskiego dotyczacego spraw karnych, nr 3-4, 2010, oprac. M. Wąsek-Wiaderek, s. 13-15, http://www.sn.pl/orzecznictwo/Orzecz_Euro_Karne/Orzecz_Euro_Karne_03-04_2010. pdf (dostęp: 18.05.2018).

18 Wyrok Europejskiego Trybunału Praw Człowieka, skarga nr 36921/07, op. cit. 
musi posiadać uprawnienia gwarantujące niezależność i niezawisłość tożsame z sędziowskimi ${ }^{19}$.

Wskutek powyższych orzeczeń instytucja asesora została zlikwidowana. Po kilku latach nieobecności i wytężonych prac nad jej nowym kształtem asesorów sądowych przywrócono do sądów powszechnych nowelizacją ustawy Prawo o ustroju sądów powszechnych ${ }^{20}$ (dalej: PUSP) z dnia 10 lipca 2015 r. z kolejnymi zmianami z 18 marca $2016 \mathrm{r}^{21}$, 11 maja $2017 \mathrm{r}^{22}, 12$ lipca $2017 \mathrm{r}^{23}$ i najnowszą z 10 maja 2018 roku $^{24}$. Charakter uzupełniający powyższych regulacji mają ustawa o Krajowej Szkole Sądownictwa i Prokuratury ${ }^{25}$ (dalej: KSSiP) w zakresie dotyczącym kolejności przyznawania wolnych stanowisk asesorskich i ustawa o Krajowej Radzie Sądownictwa ${ }^{26}$.

W ustawie kształtującej status asesora sądowego przyjęto przepisy mówiące o tym, że asesor podczas sprawowania urzędu jest niezawisły i podlega tylko Konstytucji i ustawom, oraz nakazujące mu zachowanie apolityczności ${ }^{27}$. Jest to formalnie potwierdzenie, że asesor pełniący obowiązki sędziego musi spełniać takie same kryteria jak sędzia. Ustawodawca uznał, że należy wziąć pod uwagę niewielkie doświadczenie orzecznicze asesora, dlatego tak jak wcześniej może on orzekać jedynie w sądach rejonowych. Dodatkowo spod kognicji asesora wyłączono zagadnienia dotyczące stosowania tymczasowego aresztowania w postępowaniu przygotowawczym, sprawy z zakresu prawa rodzinnego i opiekuńczego oraz rozpoznawanie zażaleń na postanowienia o odmowie wszczęcia śledztwa lub dochodzenia, na postanowienia o umorzeniu śledztwa lub dochodzenia i na postanowienia o umorzeniu dochodzenia i wpisaniu sprawy do rejestru przestępstw ${ }^{28}$.

19 M. Szeroczyńska, Lex Super omnia: Prokurator pyta - Co zrobić z asesorami sądowymi?, „Monitor Konstytucyjny" 2018, http://monitorkonstytucyjny.eu/archiwa/2471 (dostęp 10.05.2018 r.).

20 Ustawa z dnia 10 lipca 2015 r. o zmianie ustawy - Prawo o ustroju sadów powszechnych oraz innych ustaw (Dz.U. 2015 poz. 1224).

21 Ustawa z dnia 18 marca 2016 r. o zmianie ustawy - Prawo o ustroju sądów powszechnych, ustawy o Krajowej Szkole Sądownictwa i Prokuratury oraz niektórych innych ustaw (Dz.U. 2016 poz. 633).

22 Ustawa z dnia 11 maja 2017 r. o zmianie ustawy o Krajowej Szkole Sądownictwa i Prokuratury, ustawy - Prawo o ustroju sądów powszechnych oraz niektórych innych ustaw (Dz.U. 2017 poz. 1139).

23 Ustawa z dnia 12 lipca 2017 r. o zmianie ustawy - Prawo o ustroju sądów powszechnych oraz niektórych innych ustaw (Dz.U. 2017 poz. 1452).

24 Ustawa z dnia 10 maja 2018 r. o zmianie ustawy - Prawo o ustroju sądów powszechnych, ustawy o Sądzie Najwyższym oraz niektórych ustaw (Dz.U. 2018 poz. 1045).

25 Ustawa z dnia 23 stycznia 2009 r. o Krajowej Szkole Sądownictwa i Prokuratury (Dz.U. 2009 poz. 157).

26 Ustawa z dnia 12 maja 2011 r. o Krajowej Radzie Sądownictwa (Dz.U. 2011 nr 126, poz. 714).

27 Zob. art. 106j § 1-2 PUSP.

28 Zob. art. 2 §1a PUSP. 
W uregulowaniach prawnych dotyczących sposobu mianowania asesorów do czasu nowelizacji z dnia 10 maja 2018 r. niejako powtórzono rozwiązanie skrytykowane w wyrokach ${ }^{29}$ Trybunału Konstytucyjnego i Europejskiego Trybunału Praw Człowieka - na mocy art. 106i $§ 1$ ponownie przyznano Ministrowi Sprawiedliwości prawo do mianowania asesora sądowego ${ }^{30}$. Już na etapie projektu ustawy Krajowa Rada Sądownictwa w swojej opinii negatywnie oceniła te założenia, przypominając, że Minister Sprawiedliwości jest zarazem Prokuratorem Generalnym oraz przedstawicielem egzekutywy ${ }^{31}$. Mnogość i ranga uprawnień, które przysługują przedstawicielowi egzekutywy, mogą zaburzać konstytucyjny trójpodział władzy i niekorzystnie wpływać na preferowaną odrębność władzy sądowniczej. Również Komisja Europejska w związku z wszczęciem przeciwko Polsce postępowania w sprawie praworządności ${ }^{32} \mathrm{w}$ zaleceniach uzupełniających wyraziła dezaprobatę dla przyjętego rozwiązania, argumentując, że ze względu na krótki czas, przez który asesor jest uprawniony do pełnienia wotum, może być podatny na wpływy zewnętrzne, zwłaszcza ze strony Ministra Sprawiedliwości: „Minister Sprawiedliwości ma istotny wpływ na karierę zawodową asesorów sądowych, gdyż uczestniczy (...) w procesie ich selekcji i powoływania na stanowisko sędziowskie" ${ }^{\prime 33}$. Strona polska uzasadniała przyjęte przez siebie regulacje, tłumacząc, że trybunały miały zastrzeżenia przede wszystkim do możliwości odwołania asesora pełniącego wotum przez Ministra Sprawiedliwości i co do zasady to zagrażało niezawisłości, a nie sam udział Ministra Sprawiedliwości w mianowaniu $^{34}$. Nowelizacja z dnia 10 maja $2018 \mathrm{r}$. wprowadziła jednak istotne zmiany w tej materii. Prawo do mianowania asesora sądowego przysługuje obecnie Prezydentowi Rzeczypospolitej Polskiej (na wniosek Krajowej Rady Sądownictwa). Prezydent

29 Wyrok Trybunału Konstytucyjnego, SK 7/06, op. cit.

30 Ustawa z dnia 13 grudnia 2017 r. Prawo o ustroju sadów powszechnych oraz innych ustaw (Dz.U. 2018 poz. 23 zm. Dz.U. 2018 r. poz.138, Dz.U. 2018 r. poz. 106, Dz.U. 2018 r. poz.5, Dz.U. 2018 r. poz.3).

31 Opinia Krajowej Rady Sądownictwa z dnia 10 lutego 2017 r. w przedmiocie projektu ustawy o zmianie ustawy o Krajowej Szkole Sądownictwa i Prokuratury, ustawy - Prawo o ustroju sądów powszechnych oraz niektórych innych ustaw, http://krs.pl/admin/files/opinia\%20krs $\% 20 \mathrm{z} \% 20$ 10\%20lutego\%202017\%20r\%20w\%20przedmiocie\%20projektu\%20ustawy\%20o\%20zmianie $\% 20$ ustawy\%20o\%20kssip.pdf (dostęp: 10.05.2018).

32 Procedura wszczęta przeciwko Polsce wskutek zmian w sądownictwie, w styczniu 2016 r. przez Komisję Europejską.

33 Cyt. za: Zalecenie Komisji Europejskiej z dnia 26 lipca 2017 r. w sprawie praworządności w Polsce, uzupełniające zalecenia komisji (UE) 2016/1374 i (UE) 2017/146, pkt 14-17, http://www.krs.pl/ admin/files/wwm/3.rekomendacja_ke_26_07_2017pl.pdf (dostęp: 10.05.2018).

34 Stanowisko strony polskiej na Zalecenie uzupełniające Komisji Europejskiej w sprawie praworządności w Polsce z dnia 26 lipca 2017 r., pkt 6, https://for.org.pl/upload/Media/Stanowiskostro nypolskiejnaZalecenieuzupeniajceKEwspraworzadnosciwPL260717.pdf (dostęp: 10.05.2018). 
wyznacza także miejsce służbowe asesora i odbiera od niego ślubowanie ${ }^{35}$. Sąd Najwyższy w swoich uwagach, które wyraził jeszcze na etapie projektu ustawy, przychylnie odniósł się do zmiany. Wskazał jednak tkwiący w tym rozwiązaniu problem wynikający z interpretacji przepisów konstytucyjnych ${ }^{36}$. Stwierdził bowiem, że „przyznanie Prezydentowi RP uprawnienia do mianowania asesorów sądowych wydaje się zdecydowanie bardziej racjonalne (...) jednak akt taki będzie wymagał kontrasygnaty Prezesa Rady Ministrów. Wynika to z treści art. 144 ust. 2 oraz odczytanego a contrario art. 144 ust. 3 Konstytucji RP"37. Brak podjęcia odpowiednich działań prawnych wyjaśniających potrzebę i dopuszczalność kontrasygnaty $w$ akcie mianowania może spowodować powtórne zakwestionowanie konstytucyjności asesury ${ }^{38}$ i zostać potraktowany jako ingerencja władzy wykonawczej w niezawisłość sędziowską ${ }^{39}$. Warto przypomnieć, że kontrasygnata to przecież nic innego jak „uzależnienie ważności urzędowego aktu głowy państwa (...) od jego podpisania przez premiera (...) co oznacza przejęcie politycznej odpowiedzialności za ten akt. (...) jest to forma uzależnienia działań głowy państwa od akceptacji przez rząd i - pośrednio - większość parlamentarną"40. W doktrynie przeważa pogląd, że art. 144 ust. 3 jest katalogiem zamkniętym, zatem tylko akty tam wymienione są zwolnione z wymogu kontrasygnaty. Jak jednak podkreśla D. Dudek, „poprzestanie na wyłącznie literalnej wykładni (...) może prowadzić do wniosków oczywiście nieuzasadnionych" ${ }^{\prime \prime 1}$. Z art. 144 ust. 3 Konstytucji RP wynika, że do prerogatyw należą wszystkie akty urzędowe ze sfery sądownictwa i dotyczące stanowisk, które w swoim działaniu powinny być niezależne. Może to być przejawem realizacji zasady podziału i równowagi władz przez ustawodawcę. Celowe i zgodne z zamierzeniem ustawodawcy byłoby zatem zwolnienie aktu mianowania asesora od uznania Prezesa Rady Ministrów, który kieruje się głównie interesem politycznym $^{42}$. W dyskusji pojawił się także pogląd, aby zastosować wykładnię rozszerzającą do art. 144 Konstytucji i na zasadzie analogii przyjąć uprawnienie mianowania asesorów za pochodną prerogatywy powoływania sędziów. Wydaje się to wątpli-

35 Zob. art. 106i § 1-3 PUSP.

36 Zob. art. 144 Konstytucji RP.

37 Cyt. za: Uwagi do poselskiego projektu ustawy o zmianie ustawy o sadzie najwyższym oraz niektórych ustaw (druk sejmowy nr 2480) z dnia 7 maja 2018 r., s. 5, http://www.sejm.gov.pl/ Sejm8.nsf/druk.xsp?documentId=BA0BA97D31AE67F0C1258289003CE448 (dostęp: 18.05.2018).

38 D. Dudek, Ekspertyza prawna w sprawie zgodności z Konstytucja Rzeczypospolitej Polskiej zatożeń ustawy przywracającej instytucję asesora sadowego, „Krajowa Rada Sądownictwa” 2013, nr 2 s. 18.

39 D. Malec, Asesor sądowy - udana reaktywacja..., s. 543.

40 Cyt. za: Wielka Encyklopedia PWN, t. 14, Warszawa 2003, s. 314.

41 Cyt. za: D. Dudek, op. cit., s. 19.

42 Ibidem. 
wym rozwiązaniem, szczególnie w zestawieniu z wyrokiem Trybunału Konstytucyjnego ${ }^{43}$, co prawda orzekającego w sprawie Krajowej Rady Radiofonii i Telewizji [dalej: KRRiT], ale rozstrzygającego, czy przyznana przez ustawę kompetencja Prezydenta do powoływania i odwoływania Przewodniczącego KRRiT stanowi prerogatywę. Trybunał orzekł, że „brak jest podstaw do uznania, że uprawnienia Prezydenta wykonywane na podstawie art. 144 ust. 3 Konstytucji mogą być rozszerzane drogą ustawową na zasadzie »dalszego ciągu « aktu zwolnionego z kontrasygnaty, czy na zasadzie kompetencji analogicznych"44. Zagadnienie prawne wydaje się bardzo zbliżone do kwestii związanych $\mathrm{z}$ aktem mianowania asesorów. W związku z powyższym rozwiązanie sugerujące zastosowanie analogii należy uznać za nietrafione.

W opinii Sądu Najwyższego przyjęte zmiany dotyczą tylko procedury mianowania, a Minister Sprawiedliwości nadal pozostaje zwierzchnikiem służbowym asesorów, zachowując przy tym dużo uprawnień organizacyjnych, m.in. decyduje o przeniesieniu asesora lub udzieleniu mu urlopu dla poratowania zdrowia ${ }^{45}$. Należy jednak przyznać, że jest to zmiana korzystnie wpływająca na gwarancję niezawisłości i niezależności oraz zmierzająca do zachowania równowagi podziału władzy. Jest też rozwiązaniem analogicznym do procedury powoływania sędziów.

Niewątpliwą zaletę obecnie obowiązujących przepisów prawnych stanowi wprowadzenie mianowania asesora na czas nieokreślony ${ }^{46}$, chociaż pełnienie obowiązków sędziego powierzane jest tylko na okres 4 lat ${ }^{47}$. Powstaje pewna nieścisłość, gdyż z treści art. 106 xa § 1 PUSP wynika, że przed upływem tego terminu asesor może złożyć wniosek o powołanie na stanowisko sędziego ${ }^{48}$. Z kolei art. 106k $\S 2$ pkt 4 PUSP stanowi, że stosunek „służbowy asesora wygasa w przypadku nieprzedstawienia przez Krajową Radę Sądownictwa wniosku o powołanie asesora na urząd sędziego". W dodatku na mocy nowelizacji z dnia 10 maja $2018 \mathrm{r}$. została zlikwidowana instytucja asesora niepełniącego obowiązków sędziego. Co się zatem dzieje po upływie 4 lat pełnienia wotum w przypadku negatywnej oceny dotyczącej powołania na stanowisko sędziego sądu rejonowego? Jak wielu asesorów będzie kończyło kariery zawodowe po 4 latach? Odpowiedź strony polskiej wystosowana przez Ministerstwo Spraw Zagranicznych w związku z zastrzeżeniami Komisji Europejskiej stanowi, że ustawodawca kierował się założeniem, że

\footnotetext{
43 Wyrok Trybunału Konstytucyjnego z dnia 23 marca 2006 r., K 4/06.

44 Cyt. za D. Dudek, op. cit., s. 19.

45 Uwagi do poselskiego projektu..., s. 6.

46 Zob. art. 106i § 1 PUSP.

47 Zob. art. 106i § 8 PUSP.

48 Zob. art. 106xa § 1 PUSP.
} 
„Co do zasady każdy asesor, po zdaniu egzaminu sędziowskiego z wynikiem pozytywnym, powinien zostać powołany na sędziego" ${ }^{\prime \prime}$. W związku z powyższym zadeklarowany w ustawie czas nieokreślony wydaje się stwierdzeniem iluzorycznym, potwierdza się za to terminowość mianowania asesora sądowego. Nasuwają się także wątpliwości dotyczące tego, co się dzieje z asesorem, któremu odmówiono powołania sędziowskiego, i w jakim charakterze może on kontynuować swoją karierę w sądownictwie. Czego musi się dopuścić, aby zostać ocenionym negatywnie, skoro ustawodawca przewidział pewnego rodzaju domniemanie powołania asesorów? Gdyby rzeczywiście powołanie asesora na stanowisko sędziowskie było formalnością, sprzyjałoby to poczuciu stabilności i niezależności, ale umniejszałoby możliwość weryfikacji kandydatów.

Korzystnym rozwiązaniem jest to, że w przepisach zapewniono nieusuwalność asesora ${ }^{50}$, co w pełni uwzględnia uwagi wyroku Trybunału Konstytucyjnego z 2007 roku. „Żaden organ nie ma możliwości odwołania asesora, który może być złożony z urzędu tylko wyrokiem sądu dyscyplinarnego" ${ }^{51}$ albo sam zrzec się stanowiska. Przyjęte regulacje są identyczne jak rozwiązania stosowane w odniesieniu do sędziów. Jak wcześniej wspomniano, okres pełnienia obowiązków sędziego przez asesora jest ściśle określony, a ustawa nie przewiduje jego skrócenia ani wydłużenia $^{52}$. Pocieszające wydaje się to, że ustawodawca zastosował się do sugestii Trybunału Konstytucyjnego, który z kolei, odnosząc się do orzecznictwa strasburskiego, podkreślił, że okres powołania musi się wiązać z poczuciem stabilności zawodowej. Za minimalny czas spełniający te wymagania przyjęto 3 lata ${ }^{53}$. Określony przez ustawodawcę 4-letni okres pełnienia wotum wpisuje się w europejskie standardy.

W ustawie zawężono krąg podmiotów uprawnionych do odbycia asesury sądowej do aplikantów Krajowej Szkoły Sądownictwa i Prokuratury po zdanym egzaminie końcowym ${ }^{54}$. Przyjęte rozwiązanie budzi zastrzeżenia w środowiskach prawniczych, które postrzegają je jako uprzywilejowanie aplikantów KSSiP. Oczywiście utrzymano alternatywną drogę dojścia do urzędu sędziego na mocy przepisów działu II, rozdziału 1 PUSP, tj. dla przedstawicieli nauki bądź pozostałych zawodów prawniczych. Asesura jest jednak zarezerwowana wyłącznie dla adeptów

\footnotetext{
49 Stanowisko strony polskiej..., pkt 6.

50 Zob. art. 106k §1 PUSP.

51 Cyt. za: Stanowisko strony polskiej..., pkt 6.

52 I. Hayduk-Hawrylak, B. Kołecki, A. Wleklińska, Prawo o ustroju sądów powszechnych. Komentarz, Warszawa 2018, art. 106i pkt 3.

53 Cyt. za: Opinia Amnesty International w przedmiocie zagrożenia niezależności sądów i niezawisłości sędziów z dnia 5 lipca 2017 r., s. 21, http://krs.pl/admin/files/wwm/zmiany\%20w\%20 sadownictwie\%20\%20opinia\%20amnesty\%20international\%2005072017.pdf (dostęp: 29.12.2018).

54 Zob. art. 106h PUSP.
} 
KSSiP. W opinii Amnesty International w przedmiocie zagrożenia niezależności sądów i niezawisłości sędziów (sporządzonej z powodu wielu zmian legislacyjnych dotyczących władzy sądowniczej w Polsce) wyrażono zaniepokojenie. Zdaniem tej organizacji przyjęte rozwiązanie może być odebrane jako naruszenie zasady równego dostępu do służby publicznej lub na gruncie prawa międzynarodowego uznane za dyskryminację ${ }^{55}$. $Z$ drugiej strony należy przypomnieć, że scentralizowany model kształcenia przyszłych sędziów przez niezależny, wyspecjalizowany organ jest realizacją zaleceń opinii nr 4 Rady Konsultacyjnej Sędziów Europejskich (CCJE) w sprawie właściwego kształcenia przygotowawczego ${ }^{56}$. Według CCJE „szczegółowe, dogłębne i zróżnicowane szkolenie ${ }^{57 "}$ stanowi jedną z gwarancji ich niezawisłości i bezstronności. Trudno się z tym nie zgodzić, chociaż uprawnienia Ministra Sprawiedliwości względem Krajowej Szkoły Sądownictwa i Prokuratury nie są małe. Na mocy art. 1 ust. 3 ustawy o KSSiP Minister Sprawiedliwości sprawuje nadzór nad zgodnością działania szkoły z przepisami ustawowymi i statutem. Przysługuje mu także uprawnienie do nadzoru nad organizacją aplikacji sędziowskiej $^{58}$, a nawet powołuje on Dyrektora KSSiP ${ }^{59}$. Warto jednak pamiętać, że zachowano możliwość przystąpienia do konkursu dla wybitnych przedstawicieli nauki lub pozostałych profesji prawniczych, którzy dysponują odpowiednią wiedzą i doświadczeniem zawodowym, a chcieliby piastować urząd sędziego. Nie zapomniano też o referendarzach i asystentach sądowych, którzy w ramach aplikacji uzupełniającej mogą przystąpić do egzaminu sędziowskiego ${ }^{60}$.

W obecnym modelu asesury sądowej przepisy dotyczące odpowiedzialności dyscyplinarnej sędziów stosuje się odpowiednio w przypadku asesorów. Na mocy art. 106 zd PUSP asesorom przysługuje immunitet formalny. Nie mogą być oni zatrzymani i pociągnięci do odpowiedzialności karnej bez zgody sądu dyscyplinarnego, poza wyjątkiem ujęcia na gorącym uczynku. Odpowiedzialność dyscyplinarna jest przewidziana również w razie popełnienia wykroczenia. Przyjęte regulacje

55 Opinia Amnesty International..., s. 18.

56 Opinia nr 4 Rady Konsultacyjnej Sędziów Europejskich (CCJE) w sprawie właściwego kształcenia przygotowawczego i doskonalenia zawodowego sędziów na poziomie krajowym i europejskim z dnia 27 listopada 2003 r., http://www.krs.pl/pl/dzialalnosc/wspolpraca-miedzynarodowa/c,437, wspolpraca-z-rada-europy-i-rada-konsultacyjna-sedziow-europejskich-ccje/p,1/2895,informacjao-dzialaniach-i-opiniach-rady-konsultacyjnej-sedziow-europejskich (dostęp: 29.12.2018).

57 Cyt. za: ibidem, pkt 3.

58 Zob. art. 16 KSSiP.

59 Zob. art. 12 ust. 1 KSSiP.

60 Zob. rozdział 3a KSSiP. 
są odwzorowaniem immunitetu sędziowskiego i nawiązują do konstytucyjnych gwarancji niezawisłości sędziów ${ }^{61}$.

Zagadnieniem problematycznym, podniesionym przez Amnesty International, jest zmarginalizowanie roli Krajowej Rady Sądownictwa w procedurze mianowania asesorów sądowych ${ }^{62}$. Przydzielanie stanowisk asesorskich zależy od listy kwalifikacyjnej sporządzonej przez Dyrektora KSSiP na podstawie uzyskanych wyników z egzaminu sędziowskiego. W przypadku uzyskania takiej samej liczby punktów przez aplikantów o kolejności rozstrzyga średnia arytmetyczna ze wszystkich sprawdzianów w toku aplikacji, a gdy i ona będzie identyczna, stosuje się losowanie $^{63}$. Radzie przysługuje prawo sprzeciwu co do mianowania kandydata na stanowisko asesorskie w ciągu 2 miesięcy od dnia przedstawienia jej listy kwalifikacyjnej wraz z informacjami dotyczącymi kandydatów ${ }^{64}$. Niewielki wpływ na dobór asesorów mających pełnić obowiązki sędziego zdaje się potwierdzać liczba dokumentów na ich temat ${ }^{65}$. Zgodnie z art. 32a ust. 1 ustawy o KSSiP informacje ograniczają się do Krajowego Rejestru Karnego oraz właściwego komendanta wojewódzkiego lub Komendanta Stołecznego Policji. Są to dość podstawowe dane, stwierdzające jedynie, czy konkretna osoba nie pozostaje w konflikcie z prawem. Brakuje szczegółowych opinii o psychologicznych predyspozycjach i uwarunkowaniach, aktywnościach pozazawodowych czy dotychczasowych osiągnięciach. Krajowa Rada Sądownictwa jako konstytucyjny organ stojący na straży niezawisłości sędziowskiej odgrywa dużą rolę w powoływaniu sędziów ${ }^{66}$. Przyjmując założenie, że asesor jest w pewnym sensie „sędzią na próbę”, dotyczące go regulacje prawne powinny być tożsame z regulacjami odnoszącymi się do sędziów ${ }^{67}$. Sama Rada w swojej opinii odniosła się krytycznie do zaistniałej sytuacji prawnej, stwierdzając, że została wyłączona z procesu obsadzania stanowisk asesorskich ${ }^{68}$ oraz niejako pozbawiona możliwości strzeżenia niezależności i niezawisłości sądow-

61 I. Hayduk-Hawrylak, B. Kołecki, A. Wleklińska, op. cit., art. 106 zd, pkt 1.

62 Opinia Amnesty International, op. cit., s. 19.

63 Zob. art. 33a ust. 1-3 KSSiP.

64 Zob. art. 33a ust. 14-15 KSSiP.

65 Uwagi Helsińskiej Fundacji Praw Człowieka do rządowego projektu ustawy o zmianie ustawy o Krajowej Szkole Sądownictwa i Prokuratury, ustawy - Prawo o ustroju sądów powszechnych oraz niektórych innych ustaw (druk sejmowy nr 1406), Warszawa, 5 kwietnia 2017 r., http://www.hfhr.pl/wp-content/uploads/2017/04/Opinia_HFPC-asesorzy-2017-04-05.pdf (dostęp: 10.05.2018).

66 Zob. M. Chmielewska, Kompetencje Krajowej Rady Sądownictwa i ich wptyw na realizację zasady niezawisłości sędziów oraz niezależności sądów. Prolegomena, „Krytyka Prawa. Niezależne Studia nad Prawem" 2015, t. VII, s. 77-97.

67 Uwagi Helsińskiej Fundacji Praw Człowieka..., pkt 5.1.

68 Opinia Krajowej Rady Sądownictwa... 
nictwa na tym etapie. W związku z powyższym nasuwa się wniosek, że decydujące znaczenie o doborze kandydatów ma wiedza, którą zdobywa się podczas odbywania aplikacji sędziowskiej, i osiągnięte wyniki naukowe. Oczywiście w zawodzie sędziego posiadana wiedza oraz umiejętność analizy i wykładni prawa są kluczowe i sprzyjają zachowaniu niezależności i niezawisłości, jednak ze względu na specyfikę tego zawodu nie należy zapominać o predyspozycjach psychologicznych ani o standardach moralnych, którymi powinna cechować się osoba sprawująca wymiar sprawiedliwości.

W odniesieniu do uprawnień orzeczniczych asesora wątpliwości nastręcza również brak bezpośrednich przepisów kodeksu cywilnego i karnego, które jednoznacznie stanowiłby, że przyjęte regulacje prawne dla sędziów są tożsame dla asesorów sądowych. Ustawodawca uznał jednak za wystarczające unormowanie znajdujące się w art. 2 PUSP $\S 1$ „Zadania z zakresu wymiaru sprawiedliwości wykonują sędziowie" i $\S 1 \mathrm{a}$ "W sądach rejonowych zadania z zakresu wymiaru sprawiedliwości wykonują także asesorzy sądowi, z wyłączeniem (...)”. W doktrynie prawa pojawia się wątpliwość co do zakresu sprawowanej władzy sędziowskiej (zadań z zakresu wymiaru sprawiedliwości) wykonywanych przez asesorów oraz ich kompetencji w procedurze cywilnej i karnej. Pożądanym rozwiązaniem byłoby umieszczenie instytucji asesora sądowego w prost w przepisach kodeksów postępowań cywilnego i karnego - tak jak uczyniono to np. w przypadku referendarzy sądowych ${ }^{69}$.

Pomimo trudności, które przysparza regulacja prawna instytucji asesorów sądowych, większość środowisk prawniczych, na czele z Krajową Radą Sądownictwa, opowiadała się za jej powrotem. Ich zdaniem asesura sądowa powinna być odbierana jako „okres poprzedzający dożywotnią nominację sędziowską", służący "sprawdzeniu kandydata na urząd sędziego w działaniu (czyli podejmowaniu decyzji, orzekaniu, wymierzaniu sprawiedliwości), pod kątem jego predyspozycji nie tylko intelektualnych, lecz przede wszystkim także osobowościowych i moralnych"70. Krajowa Rada Sądownictwa w opiniach z 2013 r. wydanych przy pracach legislacyjnych związanych z restytucją instytucji asesora argumentowała, że asesura jest najlepszym wyjściem dla osób pozbawionych doświadczenia zawodowego, ale mających dużą wiedzę. Żadne inne rozwiązanie nie dawałoby możliwości ksztalcenia się w podejmowaniu „samodzielnych decyzji jurysdykcyjnych, rozstrzyganiu sporów, wymierzaniu sprawiedliwości i w konfrontowaniu się na sali rozpraw

69 A. Bojańczyk, O uprawnieniach asesorów sądowych do wykonania procesowych czynności sędziego de lege ferenda, „Krajowa Rada Sądownictwa” 2015, nr 3, s. 27-34.

70 Cyt. za: K. Gonera, Propozycje Krajowej Rady Sądownictwa dotyczace przywrócenia instytucji asesora sądowego (założenia wstępne), „Krajowa Rada Sądownictwa” 2013, nr 2, s. 5. 
z sytuacjami konfliktowymi ${ }^{71}$ ". Innego zdania jest Helsińska Fundacja Praw Człowieka, która przyrównuje etap asesury do zorganizowania "poligonu doświadczalnego" w sądzie, polegającym na "testowaniu na żywym organizmie" umiejętności przyszłego sędziego ${ }^{72}$. Krytycy instytucji często podkreślają, że powrót asesora sądowego jest przekreśleniem idei sędziego jako „korony zawodów prawniczych”, co przekłada się na rezygnację z wiedzy i doświadczenia zawodowego przedstawicieli innych zawodów prawniczych ${ }^{73}$. Należy jednak jeszcze raz podkreślić, że ustawodawca utrzymał możliwość powołania na urząd sędziego osoby wykonującej inny zawód prawniczy lub będącej profesorem czy doktorem habilitowanym nauk prawnych. W dodatku scentralizowany model kształcenia sprzyja ujednoliceniu standardów orzeczniczych i utrzymaniu wysokiego poziomu merytorycznego wśród kandydatów.

Podsumowując, przyjęte regulacje prawne dotyczące instytucji asesora sądowego są pozytywne, ponieważ klarownie zdefiniowano w nich sposób dojścia do zawodu sędziego. Niektóre przepisy budzą jednak wątpliwości, przede wszystkim dlatego, że w przypadku sędziów gwarancje niezawisłości są zapewnione konstytucyjnie, a w przypadku asesorów regulacje mają rangę ustawową. Wynikające z tego różnice są diametralne, szczególnie jeśli chodzi o tryb wprowadzania do nich zmian. Duża łatwość w nowelizacji ustaw może zagrażać stabilności przyjętych rozwiązań prawnych, dlatego wiele zależy od dobrej woli ustawodawcy. W związku z powyższym pojawiają się głosy, że optymalnymi regulacjami instytucji asesora sądowego byłyby regulacje na gruncie konstytucyjnym ${ }^{74}$. Nie sposób się nie zgodzić ze stwierdzeniem, że skoro asesor pełni czynności sędziego, „to musi prezentować te same walory co sędzia. Należy mu zapewnić należyte, konstytucyjne (...) umocowanie do sprawowania wymiaru sprawiedliwości ${ }^{75 "}$. Ja również przychylam się do tego stwierdzenia i uważam, że to rozwiązanie zakotwiczyłoby instytucję asesora sądowego w polskim porządku prawnym, konstytuując tym samym jego status. Skoro zdecydowano, że model asesury jest modelem dominującym w ścieżce kariery sędziowskiej, trzeba się skupić na udoskonaleniu tej instytucji, aby jak najskuteczniej zagwarantować obywatelom prawo do niezawisłego i niezależnego sądu. Trzeba ponadto pamiętać, że nawet najbardziej restrykcyjne regulacje prawne mogą się okazać nieskuteczne, jeśli wspomniane niezawisłość i bezstronność nie będą wynikać z charakteru osoby piastującej tak doniosłe stanowisko. Dlatego też do

\footnotetext{
71 Cyt. za: ibidem, s. 5.

72 Cyt. za: Uwagi Helsińskiej Fundacji Praw Człowieka..., pkt 5.

73 Ibidem.

74 D. Dudek, op. cit., s. 12.

75 Cyt. S. Polański, Glosa, „Gdańskie Studia Prawnicze - Przegląd Orzecznictwa” 2008, nr 3, s. 205.
} 
uregulowania instytucji asesora sądowego należy podejść całościowo - nie koncentrować się jedynie na pojedynczych walorach, którymi powinien się wyróżniać przyszły sędzia, takich jak wiedza czy doświadczenie, ale brać pod uwagę również kompetencje personalne, takie jak moralność, odwaga, konstruktywność czy empatia. Być może są one zbyt niedoceniane w polskiej rzeczywistości sądowej.

\section{Bibliografia}

Bodio J., Instytucja asesora sądowego, „Studia Iuridica Lublinensia” 2010, nr 13.

Bojańczyk A., O uprawnieniach asesorów sądowych do wykonania procesowych czynności sędziego de lege ferenda, "Krajowa Rada Sądownictwa” 2015, nr 3.

Dudek D., Ekspertyza prawna w sprawie zgodności z Konstytucja Rzeczypospolitej Polskiej założeń ustawy przywracającej instytucję asesora sadowego, „Krajowa Rada Sądownictwa” 2013, nr 2.

Gonera K., Propozycje Krajowej Rady Sądownictwa dotyczące przywrócenia instytucji asesora sadowego (założenia wstępne), „Krajowa Rada Sądownictwa” 2013, nr 2.

Hayduk-Hawrylak I., Kołecki B., Wleklińska A., Prawo o ustroju sądów powszechnych. Komentarz, Warszawa 2018.

Malec D., Asesor sądowy - udana reaktywacja historycznej instytucji czy nietrafna nowelizacja Prawa o ustroju sądów powszechnych? w: Nil nisi veritas. Księga dedykowana Profesorowi Jackowi Matuszewskiemu, red. M. Głuszak, D. Wiśniewska-Jóźwiak, Łódź 2016.

Malec D., Czy asesor był sędzią? Instytucja asesora sądowego w prawie o ustroju sadów powszechnych w Polsce od okresu dwudziestolecia międzywojennego. Wybrane zagadnienia, "Gdańskie Studia Prawnicze" 2012, t. XXVII.

Polański S., Glosa, „Gdańskie Studia Prawnicze - Przegląd Orzecznictwa” 2008, nr 3. Szeroczyńska M., Lex Super omnia: Prokurator pyta - Co zrobić z asesorami sądowymi?, „Monitor Konstytucyjny” 2018, http://monitorkonstytucyjny.eu/archiwa/2471

Wąsek-Wiaderek M. (oprac.) Przegląd orzecznictwa europejskiego dotyczacego spraw karnych, nr 3-4, 2010, s. 13-15, http://www.sn.pl/orzecznictwo/Orzecz_Euro_Karne/Orzecz_ Euro_Karne_03-04_2010.pdf

Wielka Encyklopedia PWN, t. 14, Warszawa 2003.

Zembrzuski T., Status ustrojowy asesora sądowego przed powierzeniem mu czynności sędziego, „Monitor Prawniczy” 2018, nr 19, https://sip.legalis.pl/document-full.seam?documentId=mjxw62zogi3damrqheytony\#tabs-metrical-info 